\title{
PRINCIPLES OF A FSK OPTICAL MODEM DESIGNED WITH VOLTAGE-FREQUENCY AND FREQUENCY-VOLTAGE CONVERTER INTEGRATED CIRCUITS
}

\author{
GERILIIM-FREKANS VE FREKANS-GERİLIM ÇEVİRİCİ TÜMDEVRELERİ \\ KULLANARAK FSK OPTIK MODEM TASARIMI PRENSİPLERİ
}

\author{
Erdem ÖZÜTÜRK ${ }^{*}$ \\ 1Electrical Electronic Engineering Department, Engineering Faculty, Uludag University, Bursa, Turkey. \\ ozuturk@uludag.edu.tr
}

\begin{abstract}
In this study the principles of a frequency shift keying optical MODEM design have been investigated. In this MODEM modulated digital data has been transmitted between transmitter and receiver via light in the free space. An infrared LED light has been modulated by FSK modulated signal at the transmitter and this modulated light has been converted to an electrical signal using a photo detector at the receiver end. The communication distance depends on both LED's radiant power and photo detector sensitivity. In many available applications the photo detector sensitivity and receiver gain have been increased to increase communication distance. In this study LED's radiant power has been increased rather than photo detector sensitivity. Beside of increasing communication distance the background noise effect has been decreased by driving LEDs with pulsed high currents.

Keywords: FSK, Optic MODEM, LED, Photo Diode
\end{abstract}

\section{Introduction}

There are many MODEM integrated circuits designed for computer communications. Some of low speed single chip MODEMs can be used to design optical MODEM. In this study, the possibilities of designing optical MODEM using voltagefrequency and frequency-voltage converter integrated circuits like XR4151 have been investigated.

Optical MODEM has been used for data communication between the computers or between one computer and its peripheral devices in the free space [1]-[3]. MODEM circuit consists of a transmitter and a receiver. The data which has been sent by the transmitter modulates one or more infrared LED's light. A photodiode which is connected as photoconductive mode has been used as photo detector at the receiver end. LEDs and photodiodes must be located such that the light can be transmitted between them. For duplex communication every computer must have both transmitter and receiver. Reducing cable connection is the one of advantage of optical MODEM. Also optical MODEM does not produce electromagnetic radiation like wireless MODEMs.

The LED has been driven with pulsed high current to increase communication distance. The data pulses must be modulated in suitable way for driving LED with high current pulses and circuits must be designed to obtain high radiant power.

\begin{abstract}
Öz
Bu çalışmada frekans ötelemeli anahtarlama kullanan optik MODEM'in tasarım prensipleri araștırılmaktadır. Bu MODEM'de sayısal veri, verici ile alıcı arasında serbest ortamda ışık ile aktarılmaktadır. Vericide kızılötesi bir LED'in ışığı FSK modülasyonlu bir ișaretle modüle edilmektedir ve modülasyonlu bu ıșık alıcı uçta fotodedektör kullanılarak elektriksel işarete dönüştürülmektedir. İletişim mesafesi hem LED'in sşık şiddetine hem de fotodedektörün duyarlılığına bağlıdır. Birçok uygulamada iletişim uzaklığını arttırmak için fotodedektörün duyarlılığı ve alıcının kazancı arttırılmaktadır. Bu çalışmada ise fotodedektörün duyarlılığından ziyade LED'in ıșık șiddeti artırılmaktadır. Bu șekilde LED'in darbeli yüksek akımla sürülmesiyle iletișim mesafesinin arttırılmasıly birlikte fon gürültüsü etkisi de azaltılmaktadır.

Anahtar kelimeler: FSK, Optik MODEM, LED, Fotodiyot
\end{abstract}

\section{Pulsed High Current Operation of LED}

LED's radiant power proportional to LED current. More radiant power can be obtained at higher LED currents. Every LED has a maximum DC current limit. But if pulse duration is short enough and if space time is long enough at pulsed high current operation mode, much higher current pulse amplitudes can be passed through the LED. There are some relations that give how much current can be passed through the LED according to LED's nominal current [4].

LED must be driven with pulsed high currents for increasing of LED's radiant power. If pulse duration and (pulse duration/period) ratio are chosen suitable in pulsed operation high currents can be passed through the LED. The radiant power of LED is proportional with LED current, so, if current is increased more radiant power can be obtain. Because of that in many applications, LED has been driven current pulses to obtain high radiant power. In the other hand, there is a current limit depends on limited power dissipation of LED and LED can be broken if current exceeds a maximum level. Although every LED has its own current limit there are some relations that give approximately a limit current value that can be passed through the LED for all different LEDs at pulsed operations. One of them is as follows:

$$
I_{p}=I_{N} \sqrt{\frac{T}{t_{p}}}
$$


In this relation $I_{p}$ is the amplitude of current pulse, $\mathrm{I}_{\mathrm{N}}$ is the nominal current, $T$ is the space time and $t_{p}$ is the pulse duration. Space time can be accepted as period in periodic current signals if space time is much long enough than pulse duration. This relation does not include any thermal or electrical characteristic parameter of LED. The thermal and electrical parameters which are related with current limit vary with current amplitude of LED and the times of pulsed operation and it is not possible to find necessary parameter values every time. Because of that this simply relation which have been given above is useful.

In FSK modulation, two different frequencies have been assigned to two different voltage levels of digital data signal (mark frequency and space frequency). Every pulses of modulated signal will drive LED and they will flow current in LED during pulse duration. According to equation (1) to increase LED radiant power, pulse duration and period of FSK signal must be chosen suitable. These durations must also be suitable for demodulation proses.

It can be possible to increase LED radiant power additionally by using some circuit technique. In this technique there are more than one LED at the transmitter and every LED shared successive FSK pulses one by one. In this technique depending on LED number " $n$ " it can be possible to increase LED current as following equation [5].

$$
I_{p}=I_{N} \sqrt{n} \sqrt{\frac{T}{t_{p}}}
$$

A serial to parallel converter circuit can be used for this purpose.

\section{Transmitter Circuit}

Transmitter circuit block diagram has been shown in Figure 1. At the input of the transmitter there is a RS232C adapter circuit. This circuit adapts RS232C electrical levels to the logic levels of logic gates which yield at the modulator circuits. There are integrated circuits for this purpose or a clipper circuit can be used for this.

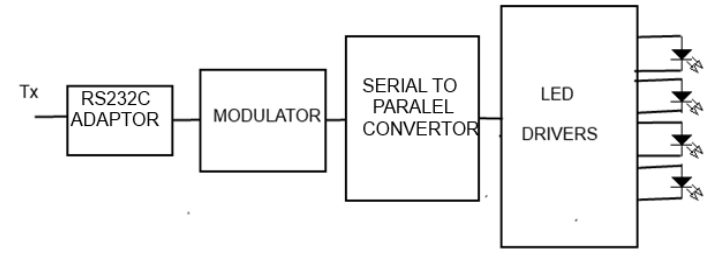

Figure 1: Transmitter circuit.

Voltage to frequency converter integrated circuits like XR4151 is designed for converting a DC voltage into a proportional pulse repetition frequency. They are also capable of converting an input frequency into a proportional output voltage. There are two different frequencies assigned to high and low levels of digital data. There are two voltage to frequency converter integrated circuit used for generate mark and space frequencies in modulator circuit (Figure 2).

An input voltage is applied to inputs of every voltage to frequency convertor integrated circuit. These voltages are obtained from a supply voltage using two voltage divider resistors. V1 voltage has a suitable value to vibrate voltage to frequency converter at mark frequency. Similarly V2 voltage has necessary value to vibrate other voltage to frequency convertor at space frequency. These two frequency converters have been produced signals which have appropriate pulse duration/period rate to drive LEDs pulsed high currents as mentioned section 1 . There are three NAND gates in modulator circuit. One of them which is at the up side of modulator circuit scheme has been connected to the output of voltage to frequency converter which produces mark frequency. Other input of this two input NAND gate is connected to one inverters output. This inverter has been inverted digital data. Since logic level of data signal is zero then inverter output and one of NAND gate input signal level is high. So this NAND gate output depends on the signal at the other input of NAND gate i.e. mark frequency signal and NAND gate output signal is inverse of mark frequency signal. At this moment the output of NAND gate which is at the down side of modulator scheme is high level since the one input is at the low level. So since one input is high level of the NAND gate which is at the output of modulator circuit and the other input is inverted mark frequency signal, mark frequency signal has been obtained at the output of modulator. Similarly, when data logic level is high the space frequency signal has been obtained at the output of modulator.

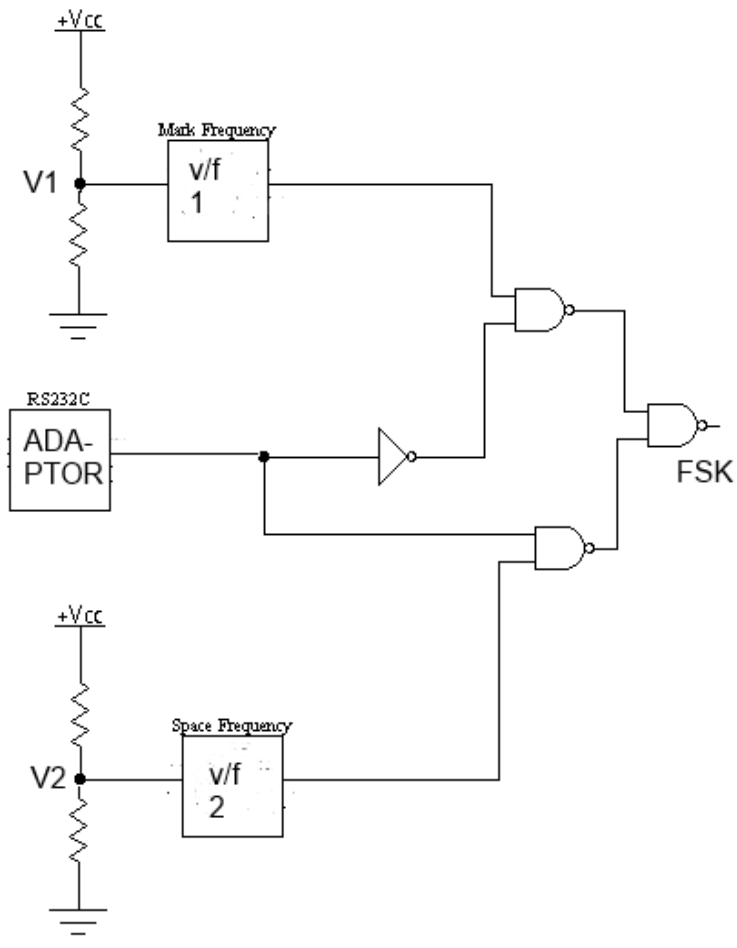

Figure 2: Modulator.

To increase LED's radiant power LED has been driven with pulsed high current pulses and to drive LED with higher amplitude current pulses as much as possible some suitable circuit techniques must be used. The circuit technique used here for this purpose based on driving different LEDs one by one with serial successive FSK pulses using a serial to parallel converter circuit (Figure 3). Serial to parallel converter circuit connected to modulator output. FSK modulated serial data has been applied to serial to parallel converter circuit input. These successive serial pulses have been shared one by one by four LEDs at the parallel outputs of serial to parallel converter. So according to equation (2) LEDs radiant power can be additionally increased. 
Every parallel outputs of serial to parallel outputs connected to one of LED driver circuit (Figure 4), [6],[8]. Transistor at the driver circuit has been used as a switching element and it provides a current gain. There is a current limiter resistor in serial with LEDs at the driver circuit. Four LEDs are used for additionally increasing of radiant power. LEDs are infrared LEDs.

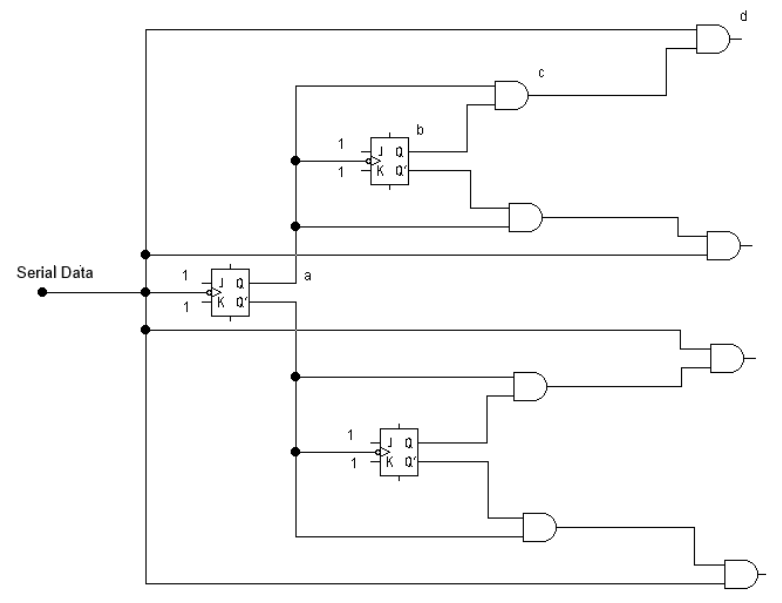

Figure 3: Serial to parallel converter circuit. High level voltage has been applied to all J and $\mathrm{K}$ inputs. All JKFFs have been worked as toggle FF.

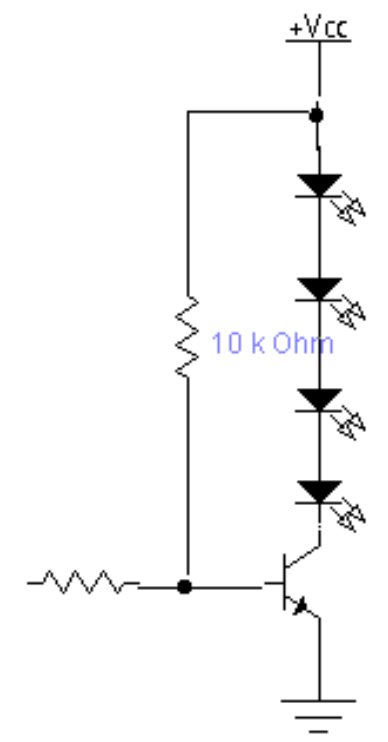

Figure 4: LED driver circuit.

\section{Receiver Circuit}

Receiver circuit has been shown in Figure 5. There is a photo detector circuit at the input of receiver. Here, photo diode is an infrared photo diode and it has been connected as photoconductive mode for work in pulsed fast operation (Figure 6).

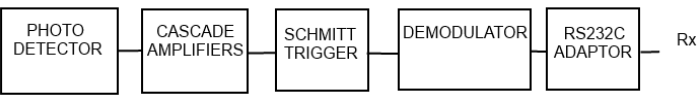

Figure 5: Receiver circuit.

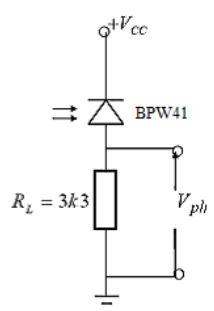

Figure 6: Photo detector circuit.

The voltage output of photodiode must be amplified. There are cascade coupled amplifiers which consist of operational amplifiers at the output of photo detector. Because of short pulse duration of pulsed signal the slew rate of operational amplifiers must be high. Schmitt trigger is used to prevent triggering by noise. After Schmitt trigger there is a FSK demodulator circuit. Demodulator can be designed using frequency to voltage converter integrated circuit (For example 7151). A sample demodulator circuit is given in (Figure 7), [9]. There is RS232C adaptor at the output of receiver which adapts demodulator output signal to the receiver computer.

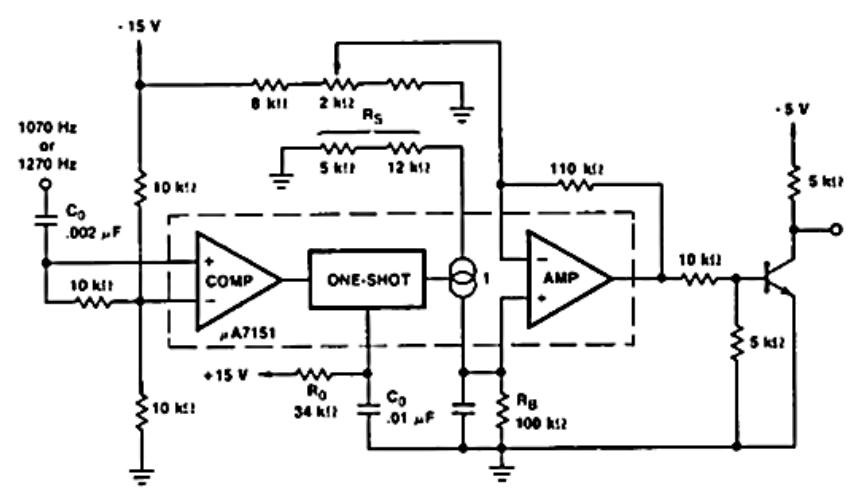

Figure 7: FSK demodulator.

\section{Conclusions}

The principles of an optical FSK MODEM design have been given in this study. To increase communication distance and to decrease background noise the radiant powers of LEDs have been increased and to increase radiant power necessary circuit techniques have been used. Background noise has been produced by other light sources in the medium like illumination light sources. This background noise effect has been decreased by driving LEDs with pulsed current operation and so raising radiant power of modulated light which carries information. Radiant power has been increased 8 times by using appropriate circuit techniques if four serial LEDs are used in each LED driver circuit which is yields in each four outputs of serial to parallel convertor.

Radiant power of LED and communication distance are inverse proportional to data speed of communication. Different data speeds have been used in data communication between computers. Low data speed must be used to increase radiant power of LEDs and communication distance in such an optical modem. Recommended data speeds are lowest data speeds such as 110 baud or 300 bps. Mark and space frequencies must be also chosen low enough because of same reason. But, on the other hand, repetition frequencies of mark and space levels of data must be high enough and different enough from each other such that data can be retrieved at the 
demodulator. Although FSK modulation optical modem has been examined here, using the other low speed modem modulation techniques like PSK in a similar optical modem can be thought.

It is important to use some optoelectronic elements such as reflectors and lenses to increase radiant power and communication distance [10].

\section{References}

[1] Ozuturk E. "Darbe Paylaşımlı Çok LED'li Optik Modem". Uludag University Journal of the Faculty of Engineering and Architecture, 17(1), 7-26, 2012.

[2] Ozuturk E. "Kızlötesi Optik Modemin Tasarlanması". Uludag University Journal of the Faculty of Engineering and Architecture, 18(1), 121-129, 2013.

[3] Ozuturk E. "Frekans Ötelemeli Anahtarlama Kullanarak Optik Modem Tasarımı". Erciyes University Journal of the Institute of Science and Technology, 24(1), 129-153, 2008.

[4] Ozuturk E. "Darbeli Akımlarda LED Akımının Ne Oranda Arttırılabileceğini Veren Bazı Bağıntıların Çok Yüksek Akımlarda Karşılaştırılması”. Uludag University Journal of the Faculty of Engineering and Architecture, 8(1), 17-24, 2003.
[5] Ozuturk E, Karlık SE. "Kızılötesi Işınlarla Açık Optik Ortamda Bilgisayarlar Arası Veri İletimi". Bursa 5. Bilgisayar-Haberleşme Sempozyumu, Bursa, Turkey, 18-22 Kasım 1998.

[6] Ozuturk E. "Atmalı Yüksek Akımlarda Kullanılan LED Sürücü Devrelerinin İncelenmesi". Uludag University Journal of the Faculty of Engineering and Architecture, 17(1), 63-77, 2012.

[7] Bradbury D. "Shedding Light on Opto-Electronics". Electronics World+Wireless World, 911-915, 1991.

[8] Hickman, I. "Hickman's Analog and RF Circuits". Reflections on Opto-Electronics, 970-974, 1995.

[9] Fairchild Semiconductors, Data Sheet, $\mu$ A4151- $\mu$ A7151. Voltage to Frequency Converter, Fairchild Linear Integrated Circuits.

[10] Ozuturk E. "LED Ișığının Algılanabilme Uzaklığını Arttırma Olanaklarının Araştırılması". Erciyes University Journal of the Institute of Science and Technology, 22(1), 83-96, 2006. 